\title{
A multicriteria model for assessing corporate sustainability in the construction industry
}

\section{Paloma R S Bezerra}

Federal University of Campina Grande: Universidade Federal de Campina Grande

Fernando Schramm ( $\nabla$ fernando@labdesides.ufcg.edu.br)

Federal University of Campina Grande https://orcid.org/0000-0003-3303-615X

\section{Vanessa B Schramm}

Federal University of Campina Grande: Universidade Federal de Campina Grande

\section{Research Article}

Keywords: Corporate Sustainability, Sustainability Assessment, Sustainability Index, Multi-Criteria Decision Making-Aid (MCDM/A), Construction industry

Posted Date: March 2nd, 2021

DOI: https://doi.org/10.21203/rs.3.rs-186058/v1

License: @ (i) This work is licensed under a Creative Commons Attribution 4.0 International License. Read Full License 


\title{
A multicriteria model for assessing corporate sustainability in the construction industry
}

\author{
Paloma Rayanne Silva Bezerra • Fernando Schramm* • \\ Vanessa Batista Schramm
}

Received: date / Accepted: date

\begin{abstract}
The construction industry is one of the most critical activities for the sustainable development of a country, generating positive and negative economic, social and environmental impacts. These aspects can be measured by Sustainability Indicators and Indices, which are useful tools for society, investors and the government in decision-making, especially when purchasing products and services, as they quantify information about a phenomenon in a given dimension of sustainability. Therefore, the objective of this study is to propose a model for assessing the sustainability of civil construction companies, considering economic, social, environmental and corporate governance criteria. These criteria are aggregated into a single index using the PROMETHEE II multicriteria method, which allows to avoid the compensation effect caused by the aggregation operators based on the additive model. The model was used to evaluate four Brazilian construction companies: Alpha, Beta, Delta and Gamma. The data of these companies were collected in a database of the Brazilian Chamber of the Construction Industry and in the sustainability's reports published by them. We concluded that the companies Alpha and Gamma, followed by the company Beta presented the best performances in corporate sustainability, while the construction company Delta has the worst level of corporate sustainability.
\end{abstract}

Keywords Corporate Sustainability · Sustainability Assessment · Sustainability Index · Multi-Criteria Decision Making-Aid (MCDM/A) · Construction industry.

\section{Introduction}

The productive sector has an important role in the sustainable development of a country. Technological innovation, efficiency in the use of natural and energy resources, encouraging the growth of local economies and improving the living standards of communities, ensuring expansion of the labor market and income generation, are the basic principles of a balanced development (Baptista Júnior and Romanel, 2013). On the other hand, it is one of the main sources of pollution of the air, water and soil, and generation of solid waste, etc.

Paloma R. S. Bezerra

Development of Systems for Supporting Sustainable Decisions (DeSiDeS), Federal University of Campina Grande (UFCG). Address: Rua Aprígio Veloso, n. ํㅜ 882, Bloco CB, Bairro Universitário, Campina Grande / Paraíba / Brazil, Zip Code: 58.429900.

Tel./Fax: +558321011574

Mob.: +55 (83) 99940-0983

E-mail: adm.pbezerra@gmail.com

Fernando Schramm

Development of Systems for Supporting Sustainable Decisions (DeSiDeS), Federal University of Campina Grande (UFCG).

Tel./Fax: +55 8321011574

Mob.: +55 83999952226

ORCID: https://orcid.org/0000-0003-3303-615X

E-mail: fernando@labdesides.ufcg.edu.br

* Corresponding author

Vanessa B. Schramm

Development of Systems for Supporting Sustainable Decisions (DeSiDeS), Federal University of Campina Grande (UFCG)

Tel./Fax: +55 8321011574

Mob.: +55 83999952446

ORCID: https://orcid.org/0000-0001-9276-5251

E-mail: vanessa@labdesides.ufcg.edu.br 
As global inequality and climate change become concerns of the society, consumers and investors are looking for products and services that have been produced through sustainability processes, practices, and policies. As a consequence, plenty of instruments for evaluation of corporate sustainability have developed and applied worldwide. Various of these instruments have been proposed by different nonprofit organizations, being the Global Reporting Initiative (GRI) one of the most frequently adopted. Moreover, many models for assessing corporate sustainability have been proposed and applied in the specialized literature.

Usually, the assessment of sustainability is given by indexes. An index is formed by the aggregation of individual indicators (single variable) and/or composite indicators, which compile two or more single indicators (Siche et al., 2007). Indicators provide quantified information about a given aspect in a given dimension of sustainability and indexes compile this information, revealing a multi-dimensional performance. Sustainability indexes can be useful for the society, investors, and government to make decisions.

Given the importance of sustainability indexes, a question that emerges is "how much they reflect what happens in companies in practice?". In a review on models for assessing corporate sustainability, we observed some critical issues. The first one is related to the dimensions of sustainability - in some cases the triple bottom line (economic, social and environmental) is not adopted, which means that the concept of sustainability is not properly evaluated, and in 10 cases, a single perspective is considered, in which governance dimension appears in three of them. The study also revealed that in various of the reviewed models, the Bellagio Principles were not met. The Bellagio Principles were created by a group of experts, at the Rockfeller Foundation in 1996, in the city of Bellagio (Italy), with the objective of guiding the development of instruments for measuring sustainability (Hardi et al., 1997). Finally, we observed that little attention has been given to the civil construction industry; in a previous study by (da Gama et al., 2014), they also pointed out that models to help operationalize sustainability in construction projects are scarce.

The civil construction sector is one of the most critical activities for sustainable development of a country, particularly developing countries, with positive and negative economic, social and environmental impacts. According to the Brazilian National Confederation of Industry (BNCI), the construction industry is the center of a macro sector, moving segments from the extraction of raw materials to the financing and maintenance services of enterprises (NCI, 2017). As for the social dimension, it has an important social role due to its capacity to generate jobs and to reverse the housing deficit and the scarce access to basic sanitation. However, the production of real estate and urban spaces causes environmental impacts throughout the process (from the extraction of raw materials to the operation of buildings and urban management): global emissions of greenhouse gases, consumption of resources and raw materials, waste produced in urban centers and construction processes, etc. In addition, it encourages the swelling of urban centers and demands the use of water, sanitation, mobility and digital information infrastructures.

Therefore, the goal of this paper is to propose a model for evaluation of sustainability of civil construction companies, which allows to evaluate sustainability considering the economic, social and environmental perspectives, as well as, observing aspects of corporate governance. These dimensions are evaluated through a set of 9 criteria that were selected based on literature review on business sustainability assessment models published in indexed peer-reviewed journals over the past two decades. This review allowed us to identify the main dimensions, criteria, sectors for which the models were applied.

These indicators are aggregated into a single index using the multicriteria method PROMETHEE II, proposed by Brans and Vincke (1985), which avoid the effect of compensation that is provoked by aggregation operators based on the additive model.

The remaining of the paper is organized into five sections: Section 2 presents a literature review on models for assessing corporate sustainability based on multicriteria methods; Section 3 presents the proposed model; Section 4 presents the discussions; and finally, conclusions are presented in Section 5.

\section{Literature Review}

We classify the models applied to assess corporate sustainability into two groups: models based on a single multicriteria method and models based on the integration of methods.

\subsection{Single method}

The AHP (Analytic Hierarchy Process) is the most applied method and in some models, the evaluation of the criteria were performed using secondary data, such as sustainability reports: Krajnc and Glavič (2005) applied AHP for evaluation of corporate sustainability in Chemical Industry; Martins et al. (2015) applied AHP to analyze a socio-economic-environmental strategy in an energy distribution company; and Lenort et al. (2017) applied this method to compare indicators in the metallurgical industry. 
In other models, the source used for evaluation of the criteria were specialists: Kluczek (2016) applied AHP to evaluate sustainability of heating boilers companies; Karaman and Akman (2018) applied AHP to classify corporate social responsibility programs in manufacturing industries; Hussain et al. (2017) applied a model, based on AHP, to assess sustainability considering economic, environmental, social management, customer management, and health and safety criteria; Mikušová (2017) applied AHP to identify the position of small companies in relation to sustainability, for which they performed an empirical research with managers of small companies in the Czech Republic; and Pérez et al. (2017) assessed corporate sustainability using the fuzzy version of AHP.

The second most frequently applied method is ANP (Analytic Network Process), which is an extension of AHP. In the ANP-based models, criteria were selected and evaluated based on judgment of specialists. The models by Poplawska et al. (2015) and Debnath et al. (2018) are based on a fuzzy version of ANP. Poplawska et al. (2015) applied ANP to select corporate social responsibility programs in the Mining Industry. Debnath et al. (2018) applied AHP to select strategies, perspectives and indicators of corporate social responsibility.

TOPSIS (Technique for Order Preference by Similarity to Ideal Solution) was used in the development of models for assessing corporate sustainability for which secondary data were used to evaluate the criteria: Afful-Dadzie et al. (2016) proposed a system to evaluate the efforts of organizations in relation to the goals of sustainable development in Bank and Financial Institutions; Kubule and Blumberga (2019) proposed a model to assess and classify the manufacturing sub-sectors.

Hsu et al. (2014) incorporated GRA (Gray Rational Analysis) technique to deal with the imprecision in the examination of sustainability indicators used to evaluate organizations. In their model, the criteria were evaluated based on secondary data.

The multicriteria method MAUT (Multi-Attribute Utility Theory) was used in Wang and Lin (2007) in the development of a sustainability index for companies and the criteria were evaluated based on secondary sources. Nara et al. (2019) used MAUT to analyze the indicators published in sustainability reports of multinational companies in Brazil using specialists as a source for evaluation of the criteria.

Lähtinen et al. (2016) used the SMART (Simple Multi-Attribute Rating Technique), which is a MAUTbased method, for evaluation of criteria in a study to assess corporate social responsibility in the forestry industry.

Bilbao-Terol et al. (2018) used secondary data for evaluation of criteria in the assess sustainability in banks and financial institutions based on the aggregation operator OWA (Ordered Weighted Averaging). Chen et al. (2015) used TODIM (acronym in Portuguese for Interactive Multi-criteria Decision Making) to assess the criteria used to assess sustainability in the construction industry.

Raj and Srivastava (2018) used a fuzzy version of the Best-Worst Method (Fuzzy-BWM) to assess manufacturing industries using indicators that were selected in secondary databases. Infante et al. (2013) used secondary data sources for evaluation indicators and applied the ELECTRE method (acronym in French of Elimination and Choix Traduisant la realite) to evaluate companies in the energy sector.

Other models are based on the use of optimization techniques, such as Goal Programming (Zhu et al., 2018; García-Martínez et al., 2019; Garcia et al., 2016), Compromise Programming (Diaz-Balteiro et al., 2011), and MOORA (Multi-Objective Optimization on the Basis of Ratio Analysis) (Küçükbay and Sürücü, 2019). In the study by Venturelli et al. (2017), an Artificial Intelligence technique was applied. In the study by Costa and Menichini (2013) the qualitative technique BSC (Balanced ScoreCard) was applied with the 2-tuple fuzzy linguistic representation model for dealing with imprecision.

\subsection{Integration of methods}

In this group, we identified that the ANP was combined in several ways: with the AHP (Vinodh et al., 2012); with COPRAS (Complex Proportional Assessment) (Rabbani et al., 2014); with TOPSIS (Zhao and Li, 2015); com AHP e PROMETHEE (Preference Ranking Organization Method for Enrichment of Evaluations) (Ren et al., 2016). These studies assessed the sustainability of the energy industry using indicators that were selected and evaluated based on evaluation of specialists.

The ANP method was combined with DEMATEL (Decision Making Trial and Evaluation Laboratory) and VIKOR (acronym in Bosnian of Higher Criteria Optimization Compromise Solution) to assess sustainability in Manufacturing and Assembly Industry considering indicators that were selected and evaluated from secondary data(Lu et al., 2016) and to assess the impact of corporate social responsibility on the implementation of internal control based on expert judgment (Liu, 2018). Tsai et al. (2009) proposed a model, based on ANP combined with DEMATEL and an optimization technique, to select sustainability actions in the manufacturing industry based on secondary data. 
Other studies combined the AHP and TOPSIS methods: Metaxas et al. (2016) evaluated corporate sustainability based on indicators selected and evaluated by experts; Rahdari (2016) considered the opinion of experts in the context of energy sector companies.

Hsu et al. (2017) incorporated the qualitative QFD (Quality Function Deployment) technique, finite difference methods, Fuzzy Extended-AHP and TOPSIS to assess the sustainability of organizations, the criteria were based on the opinion of experts.

The TOPSIS method was also used in combination with the LOWGA (Linguistic Ordered Weighted Geometric Aggregating Operator) to investigate sustainability in different sectors considering indicators evaluated by experts (Liern and Pérez-Gladish, 2018) and the Design of Experiments technique was also used in the valuation of companies in various segments based on secondary data (Bilbao-Terol et al., 2019). The PROMETHEE resilience method was used in combination with statistical tools to assess companies in the energy sector using indicators collected from secondary sources (Vivas et al., 2019).

\section{Proposed Model}

The model is divided into three phases: 3.1. problem structuring; 3.2. PROMETHEE II; and 3.3. sensitivity analysis. In the first phase, the criteria, their respective evaluation scales and preference functions associated to each criterion are presented; then, the weights of criteria and other parameters are determined; finally, the matrix of evaluation "companies versus criteria" is constructed. This matrix and remaining parameters of the first phase is the input for the second phase in which the steps of the PROMETHEE method are applied, resulting in a prioritization of the companies according to their performance in terms of sustainability (from the best to the worst). Finally, in the last phase a sensitivity analysis is performed to verify the robustness of the result, which is necessary due to the existence of imprecision and uncertainties in judgments.

\subsection{Problem structuring}

\subsubsection{Criteria}

In our research, we verified that most of the models to assess corporate sustainability are based on the Triple Bottom Line (TBL), in which economic, social and environmental dimensions are considered simultaneously. The economic dimension involves the creation of the company's economic value and its contribution to the economy; the social dimension includes performing beneficial and fair actions for employees and the community; and the environmental dimension focuses on the efficient use of natural resources so as not to compromise future generations (Elkington, 1999).

However, in various studies, we observed that corporate sustainability has been evaluated considering aspects of governance. The governance dimension involves all spheres of management, from the organization's objectives, to action plans and internal controls, performance measurement, corporate communication and relationship with its stakeholders. It deals with the relationship between stakeholders and a structure that leads the company. Includes compliance with legislation, ethics and anti-corruption, policy, strategy, supply chain management, etc. In the reviewed papers this dimension appears in combination with the TBL (Wang et al., 2018; Aras et al., 2017; K. E. K. et al., 2018; Loor Alcívar et al., 2019; Schrippe and Ribeiro, 2019); in combination with environmental and social dimensions (Muñoz-Torres et al., 2019); with economic and social dimensions (Bonsón and Bednárová, 2015); some studies evaluated sustainability considering only governance dimension (Spangenberg, 2002; Lu et al., 2016; Deng et al., 2018).

We understand that the combination of the governance dimension with the TBL concept is the most appropriate for a comprehensive assessment of corporate sustainability. In this sense, the proposed model will assess corporate sustainability of construction industry companies considering economic, social, environmental, and governance aspects.

In the reviewed models, we classified the evaluation criteria into clusters according to the similarity of the aspects that these criteria aim to evaluate in each dimension; in other words, we aggregate criteria that have different names but evaluate the same aspect in a given dimension. Then, we observed what are the most frequently applied criteria in each dimension. The result of criteria that we consider relevant for assessing corporate sustainability. These criteria and their respective description are presented in Table 1.

The next section presents the preference functions assigned to each criterion. 
Table 1 Criteria

\begin{tabular}{|c|c|c|c|}
\hline Dimension & ID & Indicator & Description \\
\hline \multirow[b]{2}{*}{ Economic } & C1 & Revenue & $\begin{array}{l}\text { The company's gross revenue per year (monetary value). A higher } \\
\text { value is preferrable to a smaller value. }\end{array}$ \\
\hline & $\mathrm{C} 2$ & Economy & $\begin{array}{l}\text { It assesses the organization's contribution to the local economy, } \\
\text { through the generation of jobs and income. The evaluation of this } \\
\text { criterion is given by the total number of employees of the company. } \\
\text { A higher value is preferrable to a smaller value. }\end{array}$ \\
\hline \multirow[b]{2}{*}{ Social } & $\mathrm{C} 3$ & $\begin{array}{l}\text { Health and } \\
\text { safety }\end{array}$ & $\begin{array}{l}\text { Number of accidents per year. A smaller value is preferable to a } \\
\text { higher value. }\end{array}$ \\
\hline & $\mathrm{C} 4$ & Community & $\begin{array}{l}\text { The evaluation of this criterion is given by the amount (monetary } \\
\text { value) that the company invests per year in benefits for the local } \\
\text { community. A higher value is preferrable to a smaller value. }\end{array}$ \\
\hline \multirow{3}{*}{ Environmental } & $\mathrm{C} 5$ & Energy & $\begin{array}{l}\text { Total of energy (MWh) that is consumer per year by the company. } \\
\text { A smaller value is preferable to a higher value. }\end{array}$ \\
\hline & C6 & Water & $\begin{array}{l}\text { Total volume of water consumed per year }\left(\mathrm{m}^{3}\right) \text {. A smaller value } \\
\text { is preferable to a higher value. }\end{array}$ \\
\hline & $\mathrm{C} 7$ & Waste & $\begin{array}{l}\text { Total weight of waste produced by the company per year (ton). A } \\
\text { smaller value is preferable to a higher value. }\end{array}$ \\
\hline \multirow[t]{2}{*}{ Governance } & $\mathrm{C} 8$ & Communication & $\begin{array}{l}\text { It involves the management of communication with stakeholders } \\
\text { (suppliers, customers, community, etc.). The evaluation of this cri- } \\
\text { terion is given by a } 5 \text {-point Likert scale: (very good ( } 5 \text { ), good (4), } \\
\text { regular (3), poor (2), very poor (1)). A higher value is preferrable } \\
\text { to a smaller value. }\end{array}$ \\
\hline & C9 & $\begin{array}{c}\text { Compliance } \\
\text { with legislation }\end{array}$ & $\begin{array}{l}\text { The evaluation of this criterion is given by the number of fines (in } \\
\text { monetary value) that is paid by the company per year. A smaller } \\
\text { value is preferable to a higher value. }\end{array}$ \\
\hline
\end{tabular}

\subsubsection{Preference Functions}

For each criterion, the analyst must assign a preference function $P_{j}(a, b)$. This function represents how the decision maker's preference changes with the difference between the degrees of performance of two alternatives $a$ and $b$ in that criterion, that is, $g_{j}(a)-g_{j}(b)$ (Brans and Vincke, 1985).

For the criteria C3 and C8, it was established that if the performance of company $a$ is slightly higher than the performance of company $b$, in one of these criteria, then company $a$ is totally preferable to company $b$. Therefore, for these criteria, the usual function (Type I) (Brans et al., 1986) is the most appropriate.

For the remaining criteria, the preference for one alternative in relation to another one was considered to increase linearly with the difference in performance between them. Based on the preference threshold considered, one alternative was found to be preferable to the others. Consequently, the V-shape criterion function suggested by PROMETHEE (Brans et al., 1986) was associated with these criteria.

The next section shows how weights were assigned to each indicator.

\subsubsection{Weights of criteria and remaining parameters}

The weights represent a measure of relative importance of the dimensions/criteria. For this type of evaluation, Munda (2008) recommends that the dimensions should have the same importance. Thus, in the proposed model, the same weight (0.25) was assigned to each dimension. Regarding the criteria, we also recommend dividing this value equally among the criteria of each dimension, but different values can be assigned according to each situation. Table 2 shows the weights assigned by the analyzes to each criterion.

Some criteria also require the definition of a preference threshold, which is a value above which the decision maker considers an alternative preferable to another one. However, the definition of these values depends on the set of companies that are being evaluated.

In the next section, we present the evaluation matrix that shows the preference relationship between the alternatives for each criterion.

\subsubsection{Matrix of Evaluation}

At this step, the matrix of evaluation alternatives versus criteria is constructed. Each cell $p_{i j}$ will contain the evaluation of the company $i(i=1,2, \ldots, m)$ in relation to the criterion $j(j=1,2, \ldots, 9)$. To construct this 
Table 2 Weights of criteria

\begin{tabular}{ccc}
\hline Dimension & Criteria & Weight \\
\hline \multirow{2}{*}{ Economic } & C1 & $0.25 / 2$ \\
& C2 & $0.25 / 2$ \\
\hline \multirow{2}{*}{ Social } & C3 & $0.25 / 2$ \\
& C4 & $0.25 / 2$ \\
\hline \multirow{2}{*}{ Environmental } & C5 & $0.25 / 3$ \\
& C6 & $0.25 / 3$ \\
& C7 & $0.25 / 3$ \\
\hline \multirow{2}{*}{ Governance } & C8 & $0.25 / 2$ \\
& C9 & $0.25 / 2$ \\
\hline
\end{tabular}

matrix, we will use data collected from primary sources (interviews and questionnaires with representatives of companies, for example) and secondary sources (information released by institutions representing the sector, sustainability certifying organizations, sustainability reports published by the companies, etc.). This evaluation must be carried out based on the evaluation scales of each criterion.

\subsection{PROMETHEE II}

The matrix of evaluation is the starting point for the application of PROMETHEE II method. Firstly, for each criterion, a matrix of alternatives versus alternatives is constructed and each cell $g_{i j}$ contain the difference of performance between the alternative of the row $i$ and the alternative of the line $j$. Thus, 9 matrixes alternatives versus alternatives are constructed (one for each criterion).

Then, based on the preference function associated to each criterion, the intensity of preference for an alternative $a$ over another $b, P_{j}(a, b)(j=1,2, \ldots, 9)$, is calculated. This is done for all criteria and for each pair of alternatives.

The next step is to determine a preference index $P(a, b)$ for each pair of alternatives using the preference intensity $P_{j}(a, b)$ and the weights $w_{j}$ given to the criteria (Table 3 ). The preference index provides the preference intensity for one alternative over another considering all criteria. The preference of an alternative $a$ over an alternative $b$ is given as follows:

$$
P(a, b)=\sum_{j=1}^{9} w_{j} P_{j}(a, b) \quad\left(\sum_{j=1}^{9} w_{j}=1\right)
$$

After that, for each alternative, two indices are calculated using the preference index: positive outranking flow, $Q^{+}(a)$, and negative outranking flow, $Q^{-}(a)$. The positive flow can be interpreted as the sum of all the advantages of one company over the others and the negative flow is the sum of its disadvantages. These indexes are calculated as follows:

$$
\begin{aligned}
Q^{+}(a) & =\sum_{a \neq b} \frac{P(a, b)}{8} \\
Q^{-}(a) & =\sum_{a \neq b} \frac{P(b, a)}{8}
\end{aligned}
$$

In PROMETHEE II, the ranking of alternatives is obtained from the net flow that was calculated for each alternative. The net flow is obtained from the difference between the positive and negative flow:

$$
Q(a)=Q^{+}(a)-Q^{-}(a)
$$

Finally, the companies are ranked in decreasing order of their net flows.

\subsection{Sensitivity analysis}

A sensitivity analysis should be performed to verify the robustness of the final ranking. For this, we recommend provoking slight changes in the weights if the criteria and then observe the effect this over the final ranking. The weights can be changed as follows: 
Table 3 Alternatives versus criteria

\begin{tabular}{ccccc}
\hline Criteria/Alternative & Alpha & Beta & Delta & Gamma \\
\hline Revenue (R\$) & $11,087,892$ & $2,388,016$ & $1,284,855$ & $2,301,008$ \\
Economy (number of employees) & 38,871 & 4,459 & 5,650 & 14,694 \\
Health and safety (number of & 134 & 122 & 167 & 340 \\
accidents per year) & & & & \\
Community (R $\$ 106)$ & 39.3 & 24.4 & 2.7 & 4.3 \\
Energy (MWh) & $1,974,763.00$ & $16,829,988.37$ & $3,163,013.38$ & $165,380.87$ \\
Water (m ${ }^{3}$ ) & $398,219.00$ & $160,812.90$ & $334,300.00$ & $2,573,775.42$ \\
Waste (ton) & 418,952 & $4,963,015$ & 13,800 & $357,986.58$ \\
Communication & 1 & 4 & 2 & 4 \\
Compliance with legislation & $550,000,000$ & 66,303 & 0 & 0 \\
\hline
\end{tabular}

Table 4 Parameters $p$.

\begin{tabular}{cccccccc}
\hline Criterion & $\mathrm{C} 1$ & $\mathrm{C} 2$ & $\mathrm{C} 4$ & $\mathrm{C} 5$ & $\mathrm{C} 6$ & $\mathrm{C} 7$ & $\mathrm{C} 9$ \\
\hline \multirow{2}{*}{$p$} & $2,000,000$ & 5,000 & $5,000,000$ & 400,000 & 500,000 & $2,000,000$ \\
& $(\mathrm{R} \$ /$ Year $)$ & & $(\mathrm{R} \$ /$ Year $)$ & $(\mathrm{t} /$ Year $)$ & $\left(\mathrm{m}^{3} /\right.$ Year $)$ & $(\mathrm{kWh} / \mathrm{Year})$ & $(\mathrm{R} \$ / \mathrm{Year})$ \\
\hline
\end{tabular}

$-1^{\text {st }}$ analysis - Increase the weight of the economic dimension from 0.25 to 0.30 and decrease the weight of the corporate governance from 0.25 to 0.20 ; then, divide the weight of each dimension equally among the criteria. Observe the effect of this in the final ranking.

$-2^{\text {nd }}$ analysis - Increase the weight of the social dimension from 0.25 to 0.30 and decrease the weight of the corporate governance from 0.25 to 0.20 ; then, divide the weight of each dimension equally among the criteria. Observe the effect of this in the final ranking.

$-3^{\text {rd }}$ analysis - Increase the weight of the environmental dimension from 0.25 to 0.30 and decrease the weight of the corporate governance from 0.25 to 0.20 ; then, divide the weight of each dimension equally among the criteria. Observe the effect of this in the final ranking.

The next section shows an application of the model.

\subsection{Numerical application}

To apply the model, we selected four Brazilian construction companies, identified in this article by: Alpha, Beta, Gamma, and Delta. These companies are references in construction and engineering in Brazil, they are large construction companies that contribute to the growth of essential sectors of the economy and to the development of the regions. Alpha is located in the State of São Paulo and has been operating in the infrastructure and industrial assembly segments for approximately 70 years. The Beta company is located in the State of Rio de Janeiro and has been operating in the civil construction, infrastructure, industrial assembly, urban mobility and energy segments for over 60 years. Gamma is headquartered in the state of Paraná and has been operating for 50 years in the following segments: infrastructure, energy, port and airport management, and highway concession. The construction company Delta was created in the State of Minas Gerais and operates in the ventures for almost 50 years.

The evaluation of these companies in relation to the economic criteria were obtained from a database provided by the Brazilian Chamber of the Construction Industry. As for the evaluation of social, environmental and governance criteria, we consulted corporate sustainability reports published by these companies: for Alpha and Delta, the source used was reports that were published in 2018; and for Beta and Gamma we collect data published in 2017 and 2016, respectively. The evaluation matrix is presented in Table 3.

The preference threshold of the criteria associated with the V-shaped criterion were defined based on the size of the companies (Table 4).

The PROMETHEE II algorithm was implemented in R Language and the following result was obtained (Table 5).

The first position on the ranking is occupied by the company Alpha whose net flow is slightly higher than the second placed company. A sensitivity analysis was performed to verify a possible inversion of position in the ranking, particularly in the first and second positions: by increasing the weight of the economic dimension and decreasing the weight of the corporate governance ( $1^{\text {st }}$ analysis), the result does not change; the ranking remains the same when we increase the weight of the social dimension and decrease the weight of the corporate governance $\left(2^{\text {nd }}\right.$ analysis $)$; the same happened when we increased the environmental dimension 
Table 5 The ranking of alternatives

\begin{tabular}{cccc}
\hline Alternative & $Q^{+}()$. & $Q^{-}()$. & $Q()$. \\
\hline Alpha & 0.444445165 & 0.342658581 & 0.101786584 \\
Gamma & 0.383127721 & 0.298260162 & 0.084867559 \\
Beta & 0.325400714 & 0.384925124 & -0.059524411 \\
Delta & 0.273883536 & 0.401013269 & -0.127129733 \\
\hline
\end{tabular}

and decrease the weight of the corporate governance ( $3^{\text {rd }}$ analysis). Therefore, we can conclude that the result is robust.

The next section presents the discussion.

\section{Discussion}

The proposed model has a strong conceptual basis. Its steps follows the process proposed by Feil and Schreiber (2017) for elaboration of sustainability indexes: selection of indicators, normalization, weighting, aggregation and formation of the index and sensitivity analysis. Moreover, the sustainability concept adopted in our model was constructed based on a systematic literature review on models for assessing corporate sustainability, which were published in peer reviewed indexed journals. The TBL perspective was incorporated in combination with an extra dimension, named corporate governance, which encompasses all spheres of management and interaction among actors who run the company.

Finally, in the proposed model, the Bellagio Principles are met: the model provides clear and mensurable evaluation criteria; a holistic perspective is adopted in the evaluation of corporate sustainability, in which aspects of governance is considered in combination with economic, social and environmental dimensions; the data necessary for the evaluation of the criteria are accessible; and the model can be adapted according to the context (for example, by changing the weights of the criteria).

Finally, a multicriteria method is used to aggregate the intra-criteria information and to provide a global performance of each alternative. The PROMETHEE method avoids the effect of compensation during the aggregation of the unidimensional evaluations, that is it reduces the possibility that a poor performance in one of the criteria is compensated by a very good performance in another.

Regarding the application, to evaluate the companies in relation to the set of criteria, we used corporate sustainability reports that were published by the companies themselves; thus, we cannot assure the absence of conflict of interests in the data. Also, for each company, we search for the most recent report, however, it is important to emphasize that the reports of each were published in different years. These reports follow the Global Reporting Initiative (GRI) guidelines, but for the same criterion, different scales were used for its evaluation; and for the application, we have made some adaptations to ensure the same measuring instrument. These aspects may have impacted on the final ranking and therefore we cannot assure that company Alpha is better than company Gamma in terms of corporate sustainability as it was suggested by the model. However, the application is important to show the applicability of the model. The proposal was applied in the civil construction sector, but it can be used to evaluate companies from different sectors.

\section{Conclusion}

This paper presented a model for assessing corporate sustainability, based on the use of the multicriteria method PROMETHEE that avoids the effect of compensation during the aggregation of criteria. The multidimensional evaluation encompasses economic, social, environmental and corporate governance aspects that were evaluated based on a set of nine mensurable criteria collected from a systematic literature review on models for assessing corporate sustainability (Revenue, Economy, Health and safety, Community, Energy, Water, Communication, Compliance with legislation). These criteria are the most frequently applied in the reviewed studies. Moreover, in our model, we define a scale for evaluation of each criteria, which allows that the evaluation is performed in the same way, irrespective of the context and the individual who is applying it.

The model was applied to evaluate civil construction companies, but it can be used to evaluate companies from different sectors. We evaluated four Brazilian construction companies. For evaluation of the criteria, we consulted a database of the Brazilian Chamber of the Construction Industry and sustainability reports of these companies.

An important contribution of this work is to allow the proposed approach to be used as a model to support managers of organizations in creating value for their shareholders and in reducing negative environmental and 
social impacts. In addition, it can assist performance certification organizations in matters of sustainability and other social actors in the role of auditors of the process and transparency of business performance.

\section{Declarations}

Funding: This study was financed in part by the Coordenação de Aperfeiçoamento de Pessoal de Nível Superior - Brasil (CAPES). Conflicts of interest/Competing interests: The authors declare that they have no onflicts of interest/Competing interests. Availability of data and material: Not applicable. Code availability: Not applicable. Ethics approval: Not applicable. Consent to participate: Not applicable. Consent for publication: Not applicable

\section{References}

Afful-Dadzie A, Afful-Dadzie E, Turkson C (2016) A TOPSIS extension framework for re-conceptualizing sustainability measurement. Kybernetes 45(1):70-86, doi:10.1108/K-04-2015-0106

Aras G, Tezcan N, Kutlu Furtuna O, Hacioglu Kazak E (2017) Corporate sustainability measurement based on entropy weight and TOPSIS. Meditari Account Res 25(3):391-413, doi:10.1108/MEDAR-11-2016-0100

Baptista Júnior JV, Romanel C (2013) Sustentabilidade na indústria da construção: uma logística para reciclagem dos resíduos de pequenas obras. URBE - Rev Bras Gestão Urbana 5(480):27, doi:10.7213/urbe.05.002.SE02

Bilbao-Terol A, Arenas-Parra M, Cañal-Fernández V, Obam-Eyang PN (2018) Multi-criteria analysis of the GRI sustainability reports: an application to Socially Responsible Investment. J Oper Res Soc 69(10):15761598, doi:10.1057/s41274-017-0229-0

Bilbao-Terol A, Arenas-Parra M, Alvarez-Otero S, Cañal-Fernández V (2019) Integrating corporate social responsibility and financial performance. Manag Decis 57(2):324-348, doi:10.1108/MD-03-2018-0290

Bonsón E, Bednárová M (2015) CSR reporting practices of Eurozone companies. Rev Contab 18(2):182-193, doi:10.1016/j.rcsar.2014.06.002

Brans J, Vincke P, Mareschal B (1986) How to select and how to rank projects: The Promethee method. Eur J Oper Res 24(2):228-238, doi:10.1016/0377-2217(86)90044-5

Brans JP, Vincke P (1985) Note-A Preference Ranking Organisation Method. Manage Sci 31(6):647-656, doi:10.1287/mnsc.31.6.647

Chen RH, Lin Y, Tseng ML (2015) Multicriteria analysis of sustainable development indicators in the construction minerals industry in China. Resour Policy 46:123-133, doi:10.1016/j.resourpol.2014.10.012

Costa R, Menichini T (2013) A multidimensional approach for CSR assessment: The importance of the stakeholder perception. Expert Syst Appl 40(1):150-161, doi:10.1016/j.eswa.2012.07.028

Debnath A, Roy J, Chatterjee K, Kar S (2018) Measuring Corporate Social Responsibility Based on Fuzzy Analytic Networking Process-Based Balance Scorecard Model. Int J Inf Technol Decis Mak 17(04):12031235, doi:10.1142/S0219622018500232

Deng D, Wen S, Chen FH, Lin SL (2018) A hybrid multiple criteria decision making model of sustainability performance evaluation for Taiwanese Certified Public Accountant firms. J Clean Prod 180:603-616, doi:10.1016/j.jclepro.2018.01.107

Diaz-Balteiro L, Voces R, Romero C (2011) Making sustainability rankings using compromise programming. An application to European paper industry. Silva Fenn 45(4):761-773, doi:10.14214/sf.103

Elkington J (1999) Cannibals with Forks: The Triple Bottom Line of 21st Century Business - Wiley. Wiley, URL https ://www . wiley.com/en-gb/Cannibals+with+Forks\%3A+The+Triple+Bottom+Line+of+21st+ Century+Business-p-9781841120843

Feil AA, Schreiber D (2017) Análise da estrutura e dos critérios na elaboração do índice de Sustentabilidade. Sustentabilidade em Debate 8(2):30-43, doi:10.18472/SustDeb.v8n2.2017.21516

da Gama JLCN, Vieira DR, Coutinho SM (2014) Perceptions of Sustainability in Civil Construction Projects: Analysis of Brazilian Construction Sites. J Mod Proj Manag 2(1), URL https ://www . journalmodernpm . com/index.php/jmpm/article/view/66

Garcia S, Cintra Y, Torres RdCS, Lima FG (2016) Corporate sustainability management: a proposed multi-criteria model to support balanced decision-making. J Clean Prod 136(A, SI):181-196, doi:10.1016/j.jclepro.2016.01.110

García-Martínez G, Guijarro F, Poyatos JA (2019) Measuring the social responsibility of European companies: a goal programming approach. Int Trans Oper Res 26(3):1074-1095, doi:10.1111/itor.12438

Hardi P, Barg S, Hodge T, Pinter L (1997) Measuring sustainable development: review of current practice. Tech. rep., Industry Canada, Ottawa, URL https://www.ic.gc.ca/eic/site/eas-aes.nsf/vwapj/ op17e.pdf/\$file/op17e.pdf 
Hsu CH, Chang AY, Luo W (2017) Identifying key performance factors for sustainability development of SMEs - integrating QFD and fuzzy MADM methods. J Clean Prod 161:629-645, doi:10.1016/j.jclepro.2017.05.063

Hsu LC, Ou SL, Ou YC (2014) A comprehensive performance evaluation and ranking methodology under a sustainable development perspective. J Bus Econ Manag 16(1):74-92, doi:10.3846/16111699.2013.848228

Hussain M, Alameeri A, Ajmal MM (2017) Prioritizing Sustainable Practices of Service Organizations. Int J Inf Syst Serv Sect 9(1):22-36, doi:10.4018/IJISSS.2017010102

Infante CEDdC, de Mendonça FM, Purcidonio PM, Valle R (2013) Triple bottom line analysis of oil and gas industry with multicriteria decision making. J Clean Prod 52:289-300, doi:10.1016/j.jclepro.2013.02.037

K E K V, S V, Gurumurthy A (2018) Modelling and analysis of sustainable manufacturing system using a digraph-based approach. Int J Sustain Eng 11(6):397-411, doi:10.1080/19397038.2017.1420108

Karaman AS, Akman E (2018) Taking-off corporate social responsibility programs: An AHP application in airline industry. J Air Transp Manag 68:187-197, doi:10.1016/j.jairtraman.2017.06.012

Kluczek A (2016) Application of Multi-criteria Approach for Sustainability Assessment of Manufacturing Processes. Manag Prod Eng Rev 7(3):62-78, doi:10.1515/mper-2016-0026

Krajnc D, Glavič P (2005) A model for integrated assessment of sustainable development. Resour Conserv Recycl 43(2):189-208, doi:10.1016/j.resconrec.2004.06.002

Kubule A, Blumberga D (2019) Sustainability Analysis of Manufacturing Industry. Environ Clim Technol 23(3):159-169, doi:10.2478/rtuect-2019-0086

Küçükbay F, Sürücü E (2019) Corporate sustainability performance measurement based on a new multicriteria sorting method. Corp Soc Responsib Environ Manag 26(3):664-680, doi:10.1002/csr.1711

Lähtinen K, Toppinen A, Mikkilä M, Toivio M, Suur-Uski O (2016) Corporate responsibility reporting in promoting social license to operate in forestry and sawmilling industries. Forestry 89(5):525-541, doi:10.1093/forestry/cpv055

Lenort R, Staš D, Wicher P, Holman D, Ignatowicz K (2017) Comparative study of sustainable key performance indicators in metallurgical industry. Rocz Ochr Sr 19:36-51, URL https://ros.edu.pl/images/ roczniki/2017/02_ROS_V19_R2017.pdf

Liern V, Pérez-Gladish B (2018) Ranking corporate sustainability: a flexible multidimensional approach based on linguistic variables. Int Trans Oper Res 25(3):1081-1100, doi:10.1111/itor.12469

Liu JY (2018) An Internal Control System that Includes Corporate Social Responsibility for Social Sustainability in the New Era. Sustainability 10(10):3382, doi:10.3390/su10103382

Loor Alcívar MI, González Santa Cruz F, Moreira Mero NY, Hidalgo Fernández A (2019) Analysis of the relationships between corporate social responsibility and corporate sustainability: empirical study of cooperativism in Ecuador. Int J Sustain Dev World Ecol 00(00):1-12, doi:10.1080/13504509.2019.1706661

Lu IY, Kuo T, Lin TS, Tzeng GH, Huang SL (2016) Multicriteria Decision Analysis to Develop Effective Sustainable Development Strategies for Enhancing Competitive Advantages: Case of the TFT-LCD Industry in Taiwan. Sustainability 8(7):646, doi:10.3390/su8070646

Martins E, Lima G, Costa H (2015) Análise Estratégica Multicritério Sócio-Econômico-Ambiental como Ferramenta de Apoio a Decisão em uma Empresa de Distribuição de Energia. Sist Gestão 10(1):96-106, doi:10.7177/sg.2015.v10.n1.a8

Metaxas IN, Koulouriotis DE, Spartalis SH (2016) A multicriteria model on calculating the Sustainable Business Excellence Index of a firm with fuzzy AHP and TOPSIS. Benchmarking An Int J 23(6):15221557, doi:10.1108/BIJ-07-2015-0072

Mikušová M (2017) To be or not to be a business responsible for sustainable development? Survey from small Czech businesses. Econ Res Istraživanja 30(1):1318-1338, doi:10.1080/1331677X.2017.1355257

Munda G (2008) Social Multi-Criteria Evaluation for a Sustainable Economy. Springer Berlin Heidelberg, Berlin, Heidelberg, doi:10.1007/978-3-540-73703-2

Muñoz-Torres MJ, Fernández-Izquierdo MÁ, Rivera-Lirio JM, Escrig-Olmedo E (2019) Can environmental, social, and governance rating agencies favor business models that promote a more sustainable development? Corp Soc Responsib Environ Manag 26(2):439-452, doi:10.1002/csr.1695

Nara EOB, Gelain C, Moraes JAR, Benitez LB, Schaefer JL, Baierle IC (2019) Analysis of the sustainability reports from multinationals tobacco companies in southern Brazil. J Clean Prod 232:1093-1102, doi:10.1016/j.jclepro.2019.05.399

NCI NCoI (2017) Construção sustentável: a mudança em curso. CNI, Brasilia, URL http://www.cbic.org.br/sustentabilidade/wp-content/uploads/sites/22/2017/10/ Caderno-Setorial-CBIC-CNI-Sustentabilidade.pdf

Pérez CÁ, Montequín VR, Fernández FO, Balsera JV (2017) Integration of Balanced Scorecard (BSC), Strategy Map, and Fuzzy Analytic Hierarchy Process (FAHP) for a Sustainability Business Framework: A Case Study of a Spanish Software Factory in the Financial Sector. Sustainability 9(4):527, doi:10.3390/su9040527 
Poplawska J, Labib A, Reed DM (2015) A hybrid multiple-criteria decision analysis framework for corporate social responsibility implementation applied to an extractive industry case study. J Oper Res Soc 66(9):1491-1505, doi:10.1057/jors.2014.116

Rabbani A, Zamani M, Yazdani-Chamzini A, Zavadskas EK (2014) Proposing a new integrated model based on sustainability balanced scorecard (SBSC) and MCDM approaches by using linguistic variables for the performance evaluation of oil producing companies. Expert Syst Appl 41(16):7316-7327, doi:10.1016/j.eswa.2014.05.023

Rahdari AH (2016) Developing a fuzzy corporate performance rating system: a petrochemical industry case study. J Clean Prod 131:421-434, doi:10.1016/j.jclepro.2016.05.007

Raj A, Srivastava SK (2018) Sustainability performance assessment of an aircraft manufacturing firm. Benchmarking An Int J 25(5):1500-1527, doi:10.1108/BIJ-01-2017-0001

Ren J, Xu D, Cao H, Wei S, Dong L, Goodsite ME (2016) Sustainability decision support framework for industrial system prioritization. AIChE J 62(1):108-130, doi:10.1002/aic.15039

Schrippe P, Ribeiro JLD (2019) Preponderant criteria for the definition of corporate sustainability based on Brazilian sustainable companies. J Clean Prod 209:10-19, doi:10.1016/j.jclepro.2018.10.001

Siche R, Agostinho F, Ortega E, Romeiro A (2007) Índices versus indicadores: precisões conceituais na discussão da sustentabilidade de países. Ambient \& Soc 10(2):137-148, doi:10.1590/S1414753X2007000200009

Spangenberg JH (2002) Institutional sustainability indicators: an analysis of the institutions in Agenda 21 and a draft set of indicators for monitoring their effectivity. Sustain Dev 10(2):103-115, doi:10.1002/sd.184

Tsai WH, Chou WC, Hsu W (2009) The sustainability balanced scorecard as a framework for selecting socially responsible investment: an effective MCDM model. J Oper Res Soc 60(10):1396-1410, doi:10.1057/jors.2008.91

Venturelli A, Caputo F, Leopizzi R, Mastroleo G, Mio C (2017) How can CSR identity be evaluated? A pilot study using a Fuzzy Expert System. J Clean Prod 141:1000-1010, doi:10.1016/j.jclepro.2016.09.172

Vinodh S, Prasanna M, Manoj S (2012) Application of analytical network process for the evaluation of sustainable business practices in an Indian relays manufacturing organization. Clean Technol Environ Policy 14(2):309-317, doi:10.1007/s10098-011-0403-z

Vivas R, Sant'anna Â, Esquerre K, Freires F (2019) Measuring Sustainability Performance with Multi Criteria Model: A Case Study. Sustainability 11(21):6113, doi:10.3390/su11216113

Wang C, Wang L, Dai S (2018) An indicator approach to industrial sustainability assessment: The case of China's Capital Economic Circle. J Clean Prod 194:473-482, doi:10.1016/j.jclepro.2018.05.125

Wang L, Lin L (2007) A methodological framework for the triple bottom line accounting and management of industry enterprises. Int J Prod Res 45(5):1063-1088, doi:10.1080/00207540600635136

Zhao H, Li N (2015) Evaluating the performance of thermal power enterprises using sustainability balanced scorecard, fuzzy Delphic and hybrid multi-criteria decision making approaches for sustainability. J Clean Prod 108:569-582, doi:10.1016/j.jclepro.2015.07.141

Zhu Y, Zhang B, Wang QA, Li W, Cai X (2018) The principle of least effort and Zipf distribution. J Phys Conf Ser 1113:012007, doi:10.1088/1742-6596/1113/1/012007 